\title{
Teaching NeuroImages: Leigh-like features expand the picture of PMPCA-related disorders
}

Anna Rubegni, MD, Rosa Pasquariello, MD, Claudia Dosi, MD, Guja Astrea, MD, Raffaello Canapicchi, MD, Filippo M. Santorelli, MD, and Claudia Nesti, PhD

Neurology ${ }^{\circledR}$ 2019;92:e168-e169. doi:10.1212/WNL.0000000000006740

\section{Correspondence}

Dr. Santorelli

filippo3364@gmail.com

\section{Figure Brain MRI}

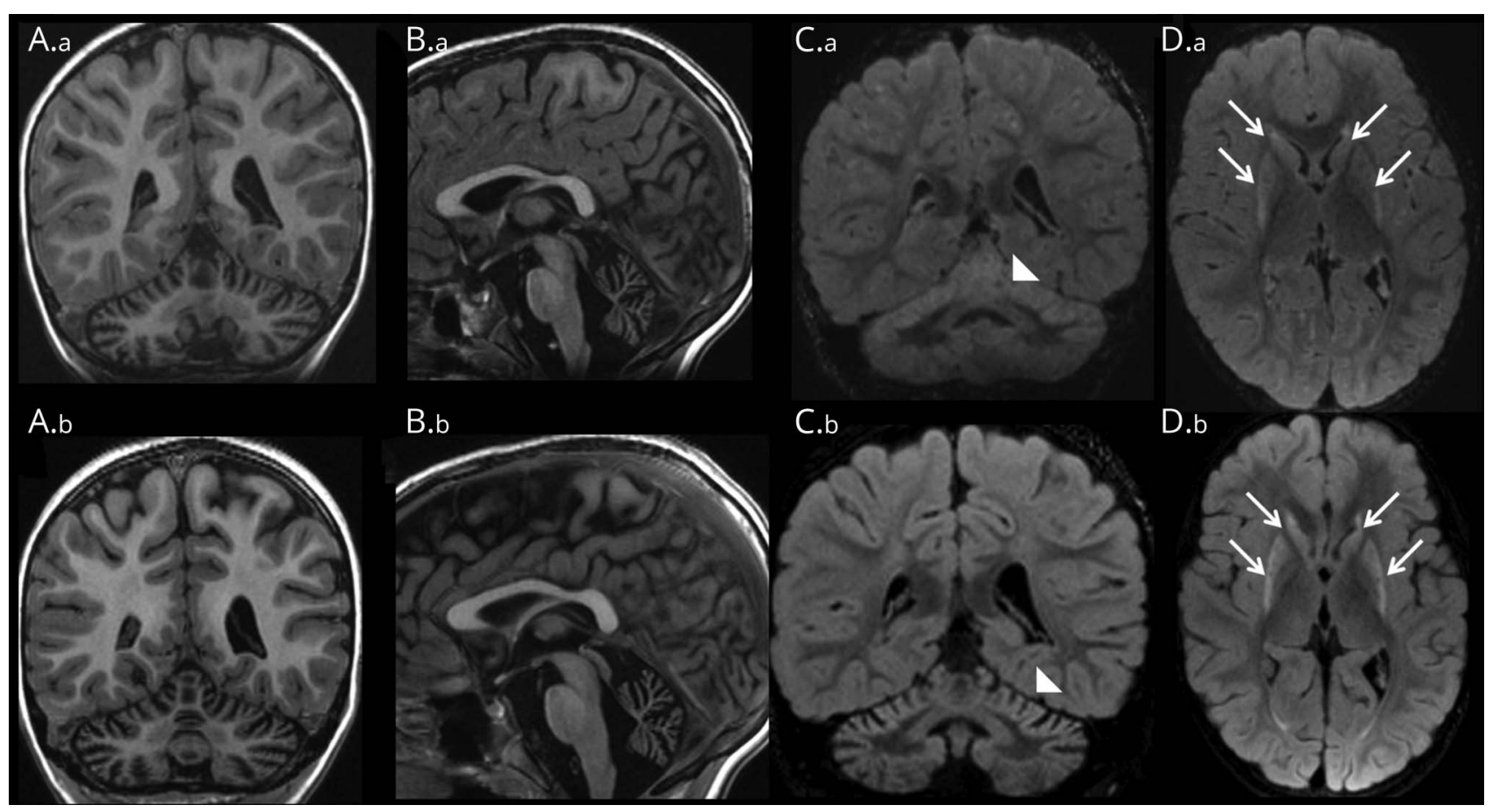

Brain MRI at age 3 (A.a-D.a) and 7 years (A.b-D.b) in a child harboring a new mutation in PMPCA. Coronal and sagittal (A.a, B.a) T1-weighted images show a shrunken appearance of the vermis and slight atrophy of the cerebellar hemispheres with widening of the cerebellar sulci. Coronal fluid-attenuated inversion recovery (FLAIR) image (C.a) reveals cortical signal increases in the superior vermis and cerebellar hemisphere (arrowhead). Axial FLAIR image (D.a) shows bilateral symmetric hyperintensity in the caudate and putamen. The main radiologic difference at follow-up at age 7 years is the increase in the striatal signal abnormality (in D.b vs D.a) (arrows).

A 7-year-old boy was referred at age 24 months with failure to thrive, global psychomotor delay, and spastic-ataxic gait with bilateral Babinski sign. Last examination revealed a further psychomotor regression and low IQ. The child could not talk, sit, or walk autonomously and showed upper limb dystonia. His Spastic Paraplegia Rating Scale ${ }^{1}$ score was 35/52.

Brain neuroimaging showed cerebellar atrophy and bilateral symmetrical hyperintensity in the striatum (figure). Blood lactate levels were slightly elevated. A muscle biopsy showed multiple defects of oxidative metabolism and signs of mitochondrial proliferation. Exome sequencing revealed the homozygous c.553C > T/p.Arg185Trp in PMPCA.

\section{MORE ONLINE}

\section{$\rightarrow$ Teaching slides}

links.lww.com/WNL/ A776

From Molecular Medicine \& Neurogenetics (A.R., C.D., F.M.S., C.N.), Neuroradiology (R.P., R.C.), and Child Neurology (G.A.), IRCCS Fondazione Stella Maris, Pisa, Italy. Go to Neurology.org/N for full disclosures. Funding information and disclosures deemed relevant by the authors, if any, are provided at the end of the article. 
PMPCA processes multiple mitochondrial proteins, including frataxin and iron-sulfur clusters involved in brain energy and oxidative metabolism. ${ }^{2}$ Leigh-like neuroimaging and spastic ataxia expand the spectrum of neurologic presentations linked to PMPCA. ${ }^{2}$

\section{Author contributions}

Dr. Rubegni: designed and conceptualized study, analyzed the data, drafted the manuscript for intellectual content. Dr. Pasquariello: major role in the acquisition of data, drafted the manuscript for intellectual content. Dr. Dosi: major role in the acquisition of data. Dr. Astrea: major role in the acquisition of data. Dr. Canapicchi: interpreted the data, drafted the manuscript for intellectual content. Dr. Santorelli: interpreted the data, revised the manuscript for intellectual content, provided funds for the study. Dr. Nesti: interpreted the data, revised the manuscript for intellectual content.

\section{Study funding}

No targeted funding reported.

\section{Disclosure}

The authors report no disclosures relevant to the manuscript. Go to Neurology.org/N for full disclosures.

\section{References}

1. Schule R, Holland-Letz T, Klimpe S, et al. The Spastic Paraplegia Rating Scale (SPRS): a reliable and valid measure of disease severity. Neurology 2006;67: 430-434.

2. Jobling RK, Assoum M, Gakh O, et al. PMPCA mutations cause abnormal mitochondrial protein processing in patients with non-progressive cerebellar ataxia. Brain 2015;138: $1505-1517$. 


\section{Neurology}

\section{Teaching NeuroImages: Leigh-like features expand the picture of PMPCA-related disorders}

Anna Rubegni, Rosa Pasquariello, Claudia Dosi, et al.

Neurology 2019;92;e168-e169

DOI 10.1212/WNL.0000000000006740

This information is current as of January 7, 2019

Updated Information \& Services

References

Subspecialty Collections

Permissions \& Licensing

Reprints including high resolution figures, can be found at: http://n.neurology.org/content/92/2/e168.full

This article cites 2 articles, 1 of which you can access for free at: http://n.neurology.org/content/92/2/e168.full\#ref-list-1

This article, along with others on similar topics, appears in the following collection(s):

Basal ganglia

http://n.neurology.org/cgi/collection/basal_ganglia

Mitochondrial disorders

http://n.neurology.org/cgi/collection/mitochondrial_disorders MRI

http://n.neurology.org/cgi/collection/mri

Spinocerebellar ataxia

http://n.neurology.org/cgi/collection/spinocerebellar_ataxia

Information about reproducing this article in parts (figures,tables) or in its entirety can be found online at:

http://www.neurology.org/about/about_the_journal\#permissions

Information about ordering reprints can be found online:

http://n.neurology.org/subscribers/advertise

Neurology ${ }^{\circledR}$ is the official journal of the American Academy of Neurology. Published continuously since 1951, it is now a weekly with 48 issues per year. Copyright (O 2019 American Academy of Neurology. All rights reserved. Print ISSN: 0028-3878. Online ISSN: 1526-632X.

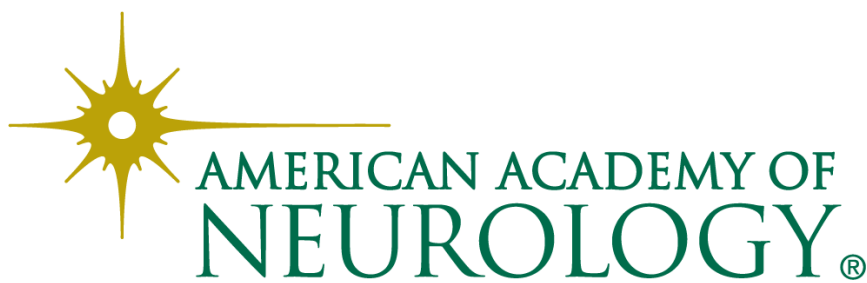

